\title{
Photochemical screening and in vitro antimicrobial analysis of chloroform, methanol and acetone extracts of leaves of Andrographis paniculata
}

\begin{abstract}
Herbs have been used for centuries to improve health and wellbeing of mankind. Mainstream modern science is now beginning to re-focus on herbs and natural plant therapies as a primary means to deal with current day health issues. Plants have been an essential part of human society since the cultivation. The aim of this study focus on the phytochemicals and in vitro analysis of the antimicrobials activities of chloroform, methanol and acetone extracts of Andrographis paniculata leaves. Phytochemical analysis revealed the presence of flavonoids, alkaloids, glycosides, steroids, phenols, tannins and saponins. In vitro antimicrobial effect of these extracts were tested on four clinical and health important microbes (Staphylococcus aureus, Escherichia coli, Aspergillus niger and Candida albicans) at 400, 200, 100, 50 and $25 \mathrm{mg} / \mathrm{ml}$ concentrations. The agar well diffusion and serial doubling dilution techniques were employed in this analysis, with azithromycin and fluconazole as the positive controls, whereas drug free and extract free solutions of chloroform, methanol and acetone were used as negative controls. All the extracts showed inhibitory effect on all the test organisms when compared with the positive and negative controls. The inhibitory zone diameter ranges from 50 to $200 \mathrm{mg} / \mathrm{ml}$ whereas the lethal concentrations ranged from 100 to $200 \mathrm{mg} / \mathrm{ml}$. The chloroform extract of this plant was more effective than methanol and acetone extracts, and Staphylococcus aureus proved more sensitive to the extracts than E. coli, Aspergillus niger and Candida albicans; nevertheless the plant extracts were considerably effective against all the organisms tested in this study. Therefore, this study justifies the use of Andrographis paniculata as potential source of antibiotics, and recommends the use of highly effective organic solvents for its extraction.
\end{abstract}

Volume 4 Issue 2 - 2019

\author{
Effiong Edet Bassey, Okonkwo Ifeayinwa, \\ Chidi Onuorah, Lilian Chioma \\ Department of Applied Microbiology and Brewing, Nnamdi \\ Azikiwe University Awka, Nigeria
}

Correspondence: Effiong Edet Bassey, Department of Applied Microbiology and Brewing, Nnamdi Azikiwe University Awka, Anambra State, Nigeria, Email Edetbassey69@gmail.com

Received: May 10, 2017 | Published: March 19, 2019

Keywords: antimicrobial activity, andrographis paniculata, phytochemical screeningminimum inhibitory concentration

\section{Introduction}

Plants have been recognized for their several lifesaving and therapeutic properties. Nearly $70 \%$ of the world's population (mainly in the developing countries) relied mostly on traditional medicine therapies as their basic way of health care. ${ }^{1}$ Andrographis paniculata Nees (Acanthaceae) known as "king of bitters" is used traditionally as a remedy for fever. The aerial parts of the plant are commonly used to treat cold, hypertension, diabetes, cancer, malaria and snake bite. ${ }^{2}$ Andrographolides ${ }^{3}$ are active components found in the aerial part of this plant. Akowuah et al., ${ }^{4}$ successfully identified and quantified two major bioactive compounds in A. paniculata, namely andrographolide and 14-deoxy-11, 12-didehydroandrographolide. Andrographolide and 14-deoxy-11, 12-didehydroandrographolide have been characterized as bitter and colourless crystalline diterpene lactone, and as colourless needles, respectively. The herb Andrographis paniculata is found growing in the forests. Medicinal plants have also been found to play an important role in the development of agro-materials to improve crop production. ${ }^{5,6}$ Moreover, the frequent use of synthetic and commercial antimicrobial drugs in treatments has led to drug resistance in animal, human and plant pathogens. ${ }^{7}$ The frequent use of synthetic preservative agents and antibiotics such as chloramphenicol in meat products has be of human health concerns. Lipid peroxidation in food lowers the nutritive value of food and causes the flavor and taste of food to deteriorate. Besides that, it raises health issues as it contributes to aging, heart disease, stroke, emphysema, mutagenesis and carcinogenesis. ${ }^{8}$ Medicinal plants showing antimicrobial and antioxidant activities may have the potential to act as safer substitutes because their molecular structures are different from those of microbes and chemical-based pharmaceuticals; therefore, their mode of action is likely to be different. ${ }^{8}$ Moreover, it is necessary to suppress lipid peroxidation to ensure that the food is safe for consumption and its flavor enhanced. The beneficial effects of plant materials typically result from the combinations of phyto chemicals that have several biological effects on microorganisms. These phyto chemicals differ from plant to plantand examples include: Anthraquinones, flavonoids, alkaloids, steroids, tannins, ${ }^{9}$ saponins, glycosides, and terpenoids. The presence of such a phytochemical of interest may lead to its further isolation, purification and characterization..$^{10}$ Then it can be used as the basis for a new pharmaceutical product. The study is aimed at phyto chemical screening and in vitro microbial analysis of Andrographis paniculata leaves

\section{Materials and methods}

\section{Equipment}

Materials for the study were of analytical grade ad were obtained from microbiology general laboratory, Nnamdi Azikiwe University, Awka.

\section{Collection of plant samples}

Andrographis paniculata leaves and stem were collected at Esther Obiakor, phase 3 plantation in Awka, Anambra state, Nigeria. It was collected on $10^{\text {th }}$ April, 2015. 


\section{Plant identification}

The plant specimen was identified and confirmed by Okeke sam. Okey of the Department of Botany, Nnamdi Azikiwe University, Awka as Andrographis paniculata, with referece to herbarium sheets(voucher umber 111), available at the herbarium of botany department.

\section{Sample preparation}

The leaves of Andrographis paniculata were dried under shade at $25^{\circ} \mathrm{C}$ for 12 days. The dried leaves were then grinded using an electric blender, and the powdered form was transferred into a clean, stoppered, labeled $250 \mathrm{ml}$ conical flask, and kept at room temperature for further use.

\section{Preparation of plant extract}

The powdered leaves $(50 \mathrm{~g})$ was weighed out and wrapped carefully in a filter paper $(24 \mathrm{~cm})$, and closed firmly at both ends. This was then packed into a soxohlet apparatus and extracted exhaustively with $500 \mathrm{ml}$ of acetone, methanol and chloroform respectively. The extract was filtered through what man No. 1 filter paper. The obtained filtrate was evaporated to dryness at $37^{\circ} \mathrm{C}$, covered tightly and preserved in the refrigerator at $4^{\circ} \mathrm{C}$ for further use.

\section{Source of test microorganism}

The pure culture of the test organisms (Staphylococcus aureus, Escherichia coli, Candida albicans and Aspergillus niger) were collected from microbiology laboratory Nnamdi Azikiwe University, Awka and sub cultured on a properly prepared Nutrient agar plate and incubated for $24 \mathrm{~h}$ at $37^{\circ} \mathrm{C}$ to check for its purity while the fungi Aspergillus niger and Candida albicans were sub cultured in Sabouraud Dextrose Agar (SDA), at $27^{\circ} \mathrm{C}$ for $48 \mathrm{~h}$ and $37^{\circ} \mathrm{C}$ respectively. After 24 hours of incubation, pure isolates were stored on agar slant for further use.

\section{Methods}

Qualitative analysis of the plant: Chemical tests were carried out on the various extracts using standard procedures to identify the constituents as described by Harborne, ${ }^{11,12}$ sofowora, ${ }^{13}$ and Senthil kumar. ${ }^{14}$ The leaf extracts were screened for alkaloids, flavonoids, steroids, phenols, Saponins, tannins, terpenoids and glycosides.

Test for tannins: To about $1 \mathrm{ml}$ of each extract, $2 \mathrm{ml}$ of $5 \%$ ferric chloride was added and observed for Brownish green or a blue-black colouration.

Test for saponins: To $1 \mathrm{ml}$ of each extract, $5-10 \mathrm{ml}$ of distilled was added and shaken in a graduated cylinder for 15 minutes. Formation of $1 \mathrm{~cm}$ layer of foam indicates the presence of Saponins.

Test for flavonoids: Three methods were used to determine the presence of flavonoids in the plant sample. ${ }^{11-13} 5 \mathrm{ml}$ of diluted ammonia solution were added to a portion of the aqueous filtrate of each plant extract followed by addition of concentrated $\mathrm{H}_{2} \mathrm{SO}_{4}$. A yellow colouration observed in each extract indicates the presence of flavonoids. The yellow colouration disappeared on standing. Few drops of $1 \%$ aluminium solution were added to a portion of each filtrate. A yellow colouration was observed indicating the presence of flavonoids. A portion of the powdered plant sample was in each case heated with $10 \mathrm{ml}$ of ethyl acetate over a steam bath for 3 minutes. The mixture was filtered and $4 \mathrm{ml}$ of the filtrate was shaken with
$1 \mathrm{ml}$ of dilute ammonia solution. A yellow colouration was observed indicating a positive test for flavonoids.

Test for alkaloids: To $2 \mathrm{ml}$ of each extract, $2 \mathrm{ml}$ of concentrated hydrochloric acid was added to the mixture above, 3drops of Mayer's reagent was added. Presence of green colour on white precipitate indicates the presence of alkaloids.

Test for glycosides: To $2 \mathrm{ml}$ of each extract, $1 \mathrm{ml}$ of glacial acetic acid and 5\% ferric chloride was added followed by 3 drops of concentrated sulphuric acid. Presence of greenish blue colour indicated the presence of glycosides.

Test for steroids: To $1 \mathrm{ml}$ of each extract, equal volume of chloroform and 3 drops of concentrated sulphuric acid was added. Formation of brown ring indicates the presence of steroids.

Test for phenols: To $1 \mathrm{ml}$ of each extract, $2 \mathrm{ml}$ of distilled water followed by 5 drops of $10 \%$ ferric chloride was added. Formation of blue or green colour indicates the presence of phenols.

Screening for antimicrobial activity: The susceptibilities of the test organisms to the plant extracts were assayed as described by Garba et al..$^{15}$

Agar diffusion method: Antimicrobial activity was evaluated using the agar well diffusion method on Mueller Hinton Agar (MHA) for bacteria and Sabouraud Dextrose Agar (SDA) for fungi. Both media were prepared according to manufacturers' recommendations, boiled to dissolve and steam sterilized in the autoclave at $121{ }^{\circ} \mathrm{C}$ for 15 minutes at $15 \mathrm{psi}$. The sterilized media was subsequently allowed to cool to $45^{\circ} \mathrm{C}$ and poured aseptically into appropriate number of labelled sterile Petri dishes and allowed to solidity. Prior to analysis, the test organisms from the agar slants were sub-cultured into Sabouraud Dextrose Broth (SDB) for fungi and Nutrient Broth (NB) for bacteria and incubated at $37^{\circ} \mathrm{C}$ for $18-24 \mathrm{hr}$ and at $25^{\circ} \mathrm{C}$ for $24-$ $48 \mathrm{hrs}$ respectively. Each organism was standardized using saline solution $(0.85 \% \mathrm{NaCl})$ and adjusted to match a turbidity of $0.5 \times 10^{8}$ cells $/ \mathrm{ml}$ using McFarland standard (through visual comparism). $0.1 \mathrm{ml}$ of the standardized suspensions were used to inoculate the surfaces of Mueller Hinton agar and Sabouraud Dextrose Agar plates $(90 \mathrm{~mm}$ in diameter) accordingly using sterile cotton swab. Three six-millimeter diameter wells were punched into each agar using a sterile cork borer. Two folds dilution of the acetone, methanol and chloroform extract of Andrographis paniculata were made and each hole was filled with the desired concentrations $(100 \mathrm{mg} / \mathrm{ml}, 50 \mathrm{mg} / \mathrm{ml}$, and $25 \mathrm{mg} / \mathrm{ml})$ of the extracts. Commercial antibiotics (Azithromycin and fluconazole as the positive controls, whereas drug free and extract free solutions of chloroform, methanol and acetone were used as negative controls to determine the sensitivity of the isolates. The plates were allowed to stand for 5 hours at room temperature for the extract to diffuse into the agar and then incubated at $37^{\circ} \mathrm{C}$ for $18-24 \mathrm{~h}$ for bacteria and at $25^{\circ} \mathrm{C}$ for 24-48h for fungi except for the yeast (Candida species) which was incubated at $37^{\circ} \mathrm{C}$. After incubation, the zones of inhibition were measured with a meter rule. The entire test was conducted in triplicate and the mean values of zone of inhibition calculated.

Determination of minimum inhibitory concentration (MIC): MIC was determined for only the extracts and on the isolates for which it showed inhibitory activity. Broth dilution technique was employed to determine the MIC of the potent extracts. Doubling dilution of the potent extracts was prepared using mueller Hinton broth (prepared) to obtain a series of dilution containing $200,100,50,25 \mathrm{mg} / \mathrm{ml}$ of 
extracts. Standardized inoculums of the test organisms (exactly $0.02 \mathrm{ml}$, equivalent to 20,000 cells) compared with the MacFarland turbidity standard was inoculated into each of the four (4) test-tubes containing $2 \mathrm{ml}$ of the mixture. Tubes containing extract-free broth were used as control, and all were incubated at $37^{\circ} \mathrm{C}$ for 24 hours. MIC was read as the least concentration that showed no growth, using turbidity as a measure.

Determination of minimum lethal concentration (MLC): The $\mathrm{MBC}$ was determined by collecting $0.2 \mathrm{ml}$ of broth culture from the tubes used for the MIC determination (starting from the MIC point backwards) and sub culturing onto fresh extract-free and drug-free solid agar plates. The plates were incubated at $37^{\circ} \mathrm{C}$ for 24 hours. The least concentration that didn't show any growth after $24 \mathrm{~h}$ of incubation or the lowest concentration of the extracts that killed $99.9 \%$ of the bacterial inoculum was taken as the minimal bactericidal concentration was regarded as the MBC.

Determination of minimal fungicidal concentration (MFC): The Minimal Fungicidal Concentration was determined by sub culturing the test dilutions with no visible growth on Sabouraud Dextrose Agar and further incubated for $48 \mathrm{~h}$. The lowest concentration that killed $99.9 \%$ of the fungal inoculum was taken as the minimal fungicidal concentration.

Preparation of stock solutions of extract: The stock solutions of the extracts were prepared by dissolving $0.8 \mathrm{~g}$ of each extract in $2 \mathrm{ml}$ of dimethyl sulfoxide (DMSO) to give a concentration of $400 \mathrm{mg} / \mathrm{ml}$. This was allowed on the bench overnight to dissolve completely.

\section{Quantitative determinations of leaf extract of Andrographis paniculata}

The plant extracts was determined quantitatively using the following methods below.

\section{Estimation of tannins}

Estimation of Tannins was carried out using Folin-Denis reagent as reported by AOAC (1980) with some modifications. To $0.20 \mathrm{~g}$ of the sample $20 \mathrm{ml}$ of $50 \%$ methanol was added. This was shaken thoroughly and placed in a water bath at $80^{\circ} \mathrm{C}$ for $1 \mathrm{~h}$ to ensure uniform mixing. The extract was filtered into a $100 \mathrm{ml}$ volumetric flask, followed by the addition of $20 \mathrm{ml}$ of distilled water, $2.5 \mathrm{ml}$ of Folin-Denis reagent and $10 \mathrm{ml}$ of $17 \%$ aq. $\mathrm{Na}_{2} \mathrm{CO}_{3}$ and was thoroughly mixed. The mixture was made up to $100 \mathrm{ml}$ with distilled water; it was then mixed and allowed to stand for $20 \mathrm{~min}$. The bluish-green color developed at the end of the reaction mixture of different concentrations ranges from 0 to $10 \mathrm{ppm}$. The absorbance of the tannic acid standard solutions as well as sample was measured after color development at $760 \mathrm{~nm}$ using the AJI-C03 UV-VIS spectrophotometer. Results were expressed as $\mathrm{mg} / \mathrm{g}$ of tannic acid equivalent using calibration.

\section{Alkaloid was estimated using Harborne ( 1 973) method}

Five $(5 \mathrm{~g})$ of the sample was weighed into $250 \mathrm{ml}$ beaker and $200 \mathrm{ml}$ of $10 \%$ acetic acid in ethanol was added and covered, the mixture was allowed to stand for 4hour. It was then filtered and the extract was concentrated on a water bath to one quarter of the original volume. Concentrated ammonium hydroxide was then added in a drop-wise manner to the extract until precipitation was complete. The whole solution was allowed to settle and the precipitate was collected and was washed with $0.1 \%$ dilute ammonium hydroxide and was then filtered. The residue was the alkaloid, which was then dried and weighed.

\section{Flavonoids determined using the method of Bohm \& Koapai-Abyazan (1994)}

$10 \mathrm{~g}$ of the plants sample was extracted repeatedly with $100 \mathrm{ml}$ of $80 \%$ aqueous methanol at room temperature. The whole solution was filtered through What man's filter paper NO.42(125mm). The filtrate was then transferred into crucible and evaporated into dryness over a water bath and weighed to a constant weight.

\section{Saponins determination}

Quantitative determination of Saponins was done using the method of Obadoni. ${ }^{16}$ The powdered sample $(20 \mathrm{~g})$ was added to $100 \mathrm{ml}$ of $20 \%$ aqueous ethanol and kept in a shaker for $30 \mathrm{~min}$. The samples were heated over a water bath for $4 \mathrm{~h}$ at $55^{\circ} \mathrm{C}$. The mixture was then filtered and the residue re-extracted with another $200 \mathrm{ml}$ of $20 \%$ aqueous ethanol. The combined extracts were reduced to approximately $40 \mathrm{ml}$ over the water bath at $90^{\circ} \mathrm{C}$. The concentrate was transferred into a $250 \mathrm{ml}$ separatory funnel and extracted twice with $20 \mathrm{ml}$ diethyl ether. The ether layer was discarded while the aqueous layer was retained and to which $60 \mathrm{ml} n$-butanol was added. The $n$-butanol extracts were washed twice with $10 \mathrm{ml}$ of $5 \%$ aqueous sodium chloride. The remaining solution was heated on a water bath. After evaporation, the samples were dried in the oven at $40^{\circ} \mathrm{C}$ to a constant weight. The Saponins content was calculated using the formula: \% Saponins=final weight of sample/initial weight of extracts x 100 .

\section{Determination of total phenols by spectrophotometer}

The fat free sample was boiled with $50 \mathrm{ml}$ of ether for the extraction of the phenolic component for 15 minutes. $5 \mathrm{ml}$ of the extract was taken into a $50 \mathrm{ml}$ flask, and then $10 \mathrm{ml}$ of distilled water was added. $2 \mathrm{ml}$ of ammonium hydroxide solution and $5 \mathrm{ml}$ of concentrate amyl alcohol was also added. The samples were made up to mark and left to react for 30minutes for colour development. ${ }^{17}$ It was then measured at $505 \mathrm{~nm}$. These data was used to estimate the total phenolic content using a standard calibration curve that was obtained from various diluted concentrations of gallic acid.

\section{Glycosides determination}

$5 \mathrm{~g}$ of the sample was soaked in distilled water for 3 hours $1 \mathrm{ml}$ of the extract was measured into a test tube, and $2 \mathrm{mls}$ of DNS reagent added. The test tube is placed in a beaker of boiling water and boiled for 5 minutes, cooled in cold water, and $10 \mathrm{mls}$ of distilled water added. The absorbance was read at $540 \mathrm{~nm}$ using spectronic 20: The Glycoside content was calculated using the formula: $\%$ Glycoside $=$ conc $\mathrm{x}$ vol of extract $\mathrm{x} 100 / 1000 \mathrm{x}$ weight of sample.

\section{Results and discussion}

\section{Preliminary phytochemical screening}

Preliminary phyto chemical screening of chloroform, methanol and acetone extracts is presented in Table 1 . The results showed that Glycosides phenols and steroids are present in the three extracts. Saponins are present in chloroform and methanol extracts, tannins are present in methanol and acetone extracts while alkaloid and flavonoids were absent in methanol and acetone extracts respectively, but present in chloroform extracts. 
Table I Experimental results on qualitative analysis of andrographis paniculato

\begin{tabular}{llll}
\hline $\begin{array}{l}\text { Phyto } \\
\text { constituents }\end{array}$ & $\begin{array}{l}\text { Methanol } \\
\text { extract }\end{array}$ & $\begin{array}{l}\text { Acetone } \\
\text { extract }\end{array}$ & $\begin{array}{l}\text { Chloroform } \\
\text { extract }\end{array}$ \\
\hline Alkaloids & L & L & L \\
Flavonoids & - & - & + \\
Saponins & + & - & + \\
Glycosides & ++ & - & + \\
Phenol & ++ & + & + \\
Tannins & + & ++ & + \\
Steroids & ++ & + & - \\
\hline
\end{tabular}

L, Leaves, -absent, +present, ++moderate, +++maximum

\section{Quantitative phytochemical screening}

Quantitative determinations of phyto constituents such as alkaloids, flavonoids, saponins,tannins and phenols were carried out and the result presented in Table 2. The results showed that chloroform extract of A. paniculata exhibited higher yield in flavonoids (19.51) and alkaloids (6.73) compared to methanol and acetone extracts both of which exhibited higher yields of Glycosides, $(8.32,6.12)$, Phenol, $(7.95,8.40)$, tannins, $(6.64,6.21)$ and Steroids, $(2.57$ 0.81). Saponins however was found only in methanol and chloroform extracts (4.09, 3.01).

Table 2 Experimental results on quantitative analysis of andrographis paniculata leaf extracts using methanol, acetone and chloroform in percentage \%

\begin{tabular}{llll}
\hline Phytoconstituents & Methanol & Acetone & Chloroform \\
\hline Alkaloids & 0 & 0 & 6.73 \\
Flavonoids & 0 & 0 & 19.51 \\
Glycosides & 8.32 & 6.12 & 3.19 \\
Phenol & 7.95 & 8.4 & 0.71 \\
Saponins & 4.09 & 0 & 3.01 \\
Tannins & 6.64 & 6.21 & 0 \\
Steroids & 2.57 & 0.81 & 0.23 \\
\hline
\end{tabular}

\section{Antimicrobial activity}

Results of the antimicrobial activity screening of methanol extracts of leaf of Andrographis paniculata revealed significant antimicrobial activity against all tested microbial strains. The results are shown in Table 3. The chloroform extract of leaf of Andrographis paniculata showed more significant activity against all tested microbial organisms, followed bymethanol extract and then acetone extract. The maximum antimicrobial activity of chloroform extracts of Andrographis paniculata was exhibited against Staphylococcus aureus. The effects of Andrographis paniculata ${ }^{18}$ leaf on the test microorganisms may be due to the presence of the above phytochemical components. The various phyto chemical constituents found are known to be beneficial in medicinal science. Antibacterial activities of the extracts could be attributed to the presence of several types of compounds belonging to different classes, such as flavonoids ${ }^{19}$ and the more polar thermo-labile and thermo-stable phenolics. ${ }^{20}$ The flavonoids have been the nature's biological response modifiers, because of their ability to modify the body's reaction to allergies and viruses. They also have anti-allergic, anti-inflammatory, ${ }^{21}$ antioxidant, anti-microbial and anti-cancer activities. ${ }^{22}$ The phenols along with antimicrobial activity also show astringent properties..$^{23}$ Alkaloids generally present play some metabolic role and control development in living system. ${ }^{24}$ They have been used in the treatment of diseases like malaria. They also have protective function and are used as medicine especially the steroidal alkaloids. ${ }^{25}$ Generally, glycosides are non volatile and lack fragrance but cleaving the glycosidic bond yields the aglycone, which appears volatile and fragrant. Glycosides serve as defense mechanisms against many micro-organisms. ${ }^{26}$ It is also known that steroidal compounds are of importance and interest in pharmacy due to their relationship with sex compounds Okwu DE. ${ }^{27}$ Plant steroids are known to be important for their cardiotonic and insecticidal activities. Tannins at low concentration can inhibit the growth of microorganisms and act as an antifungal agent at higher concentration by coagulation effect on the protoplasm of microorganism. ${ }^{28}$ Saponins protect against hypercholesterolemia and has antibiotic properties, thus protects against microbes and fungi. It is also in the management of inflammations. It is also used to allow antibody access in intracellular proteins. In medicine, it is used for hyperglycaemia, antioxidant, anticancer, weight loss. ${ }^{29}$ The extracts of Andrographis paniculata ${ }^{30,31}$ leaf showed zones of Inhibition, ranging from $15-30 \mathrm{~mm}$, excluding that of controls (Figure $1 \&$ Figure 2). The Results revealed that chloroform extracts was significantly active against Staphylococcus aureus followed by Escherichia coli, Aspergillus niger and Candida albicans in that order. Also methanol extracts were more effective against Staphylococcus aureus followed by Escherichia coli, Aspergillus niger and Candida albicans in that order. The same trend was observed in the acetone extracts. On the whole, chloroform extracts gave a higher antimicrobial activity than methanol ${ }^{32}$ and acetone extracts respectively. The result of the Minimum Inhibitory Concentration (MIC) Figure 3 assay is shown in Table 4 Chloroform extracts exhibited the highest inhibition against Staphylococcus aureus and Escherichia coli at $50 \mathrm{mg} / \mathrm{ml}$ but $100 \mathrm{mg} / \mathrm{ml}$ against Aspergillus niger and Candida albicans. Also methanol extracts showed inhibition against Staphylococcus aureus and Escherichia coli at $100 \mathrm{mg} / \mathrm{ml}$ but $200 \mathrm{mg} / \mathrm{ml}$ against Aspergillus niger and Candida albicans. While acetone extracts inhibited Staphylococcus aureus and Escherichia coli at $100 \mathrm{mg} / \mathrm{ml}$ but showed no effect against Aspergillus niger and Candida albicans. The Minimum Lethal Concentration (MLC) Figure 4 of the extracts is shown in Table 5. Generally the Chloroform extracts exhibited the highest lethal effect against Staphylococcus aureus at $100 \mathrm{mg} / \mathrm{ml}$ and Escherichia coli at $200 \mathrm{mg} / \mathrm{ml}$ but $200 \mathrm{mg} / \mathrm{ml}$ against Aspergillus niger and Candida albicans respectively, followed by methanol extracts which showed its lethal effect against all the organisms at $200 \mathrm{mg} /$ $\mathrm{ml}$ concentrations. ${ }^{33,34}$ However the acetone extracts showed its lethal effect against Staphylococcus aureus at $200 \mathrm{mg} / \mathrm{ml}$ but has no effect against Escherichia coli, Aspergillus niger and Candida albicans respectively Figure 5.

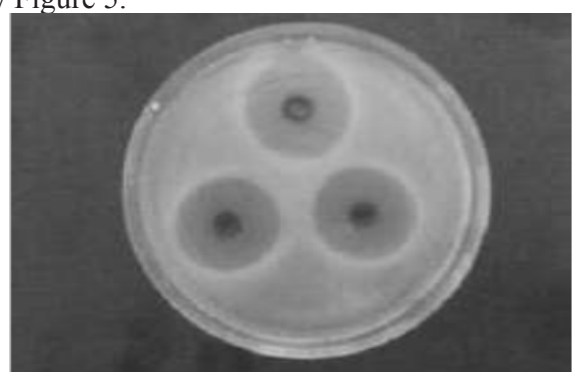

Figure I Preliminary Screening of antibacterial activity of extracts of methanol, acetone and chloroform on escherichia coli. 


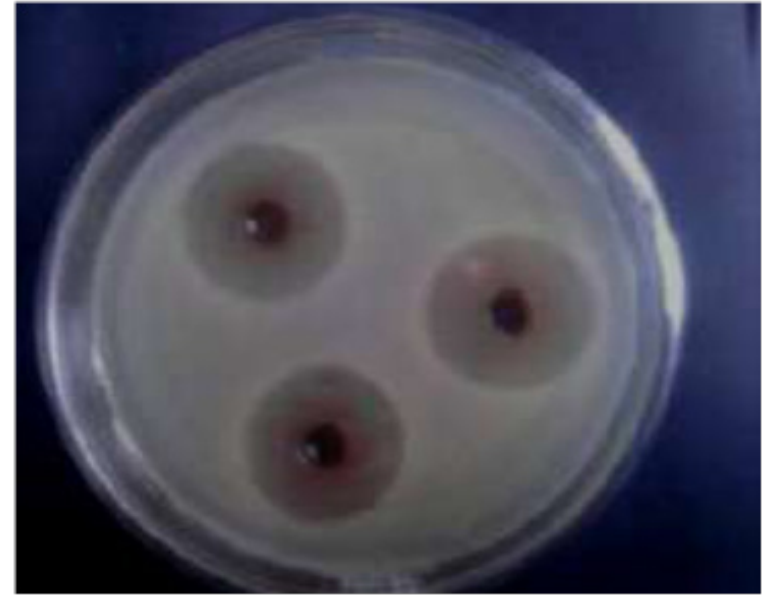

Figure 2 Preliminary screening of antibacterial activity of extracts of methanol, acetone and chloroform on staphylococcus aureus.'

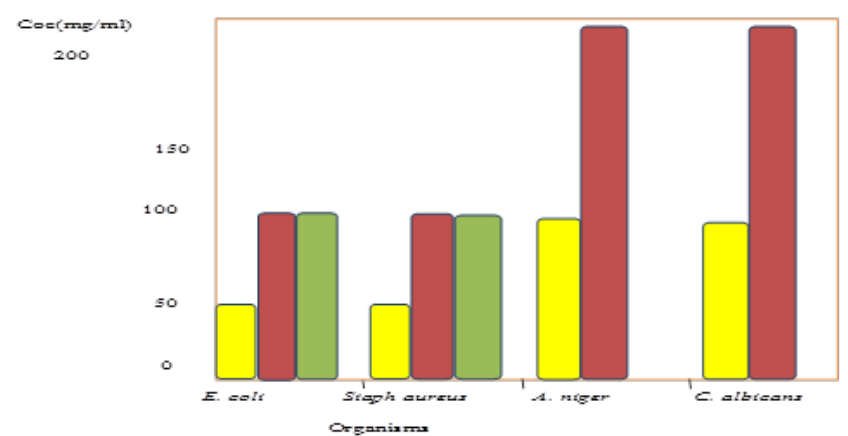

Figure 3 Minimum inhibitory concentration (MIC) based on microbial turbidit

Chloroform extract of Andrographis paniculata
Methanol extract of Andrographis paniculata

Acetone extract of Andrographis paniculata

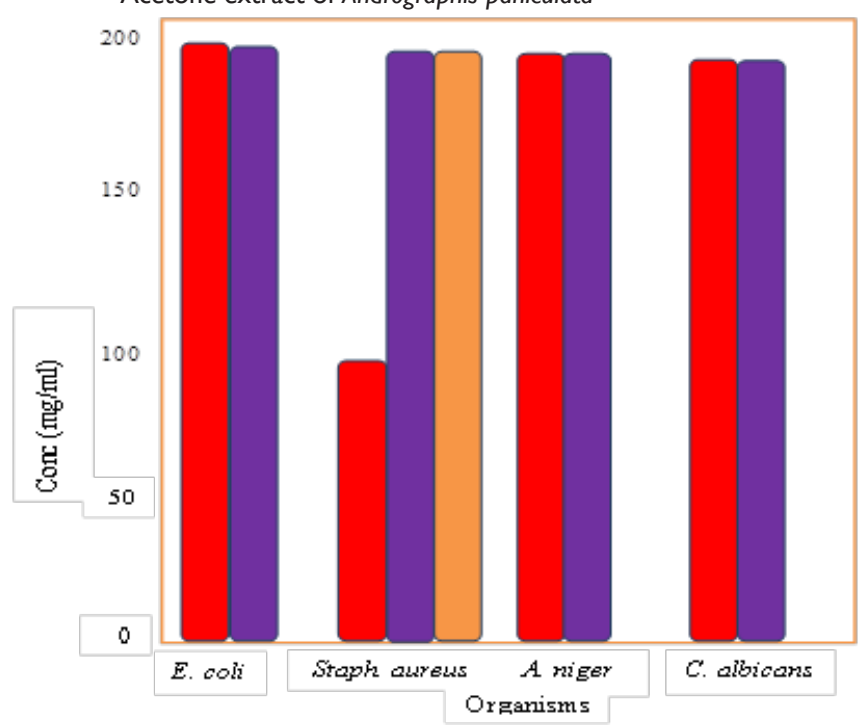

Figure 4 Minimum lethal concentration (MLC) based on microbial growth.

Chloroform extract of Andrographis paniculata

Methanol extract of Andrographis paniculata

Acetone extract of Andrographis paniculata

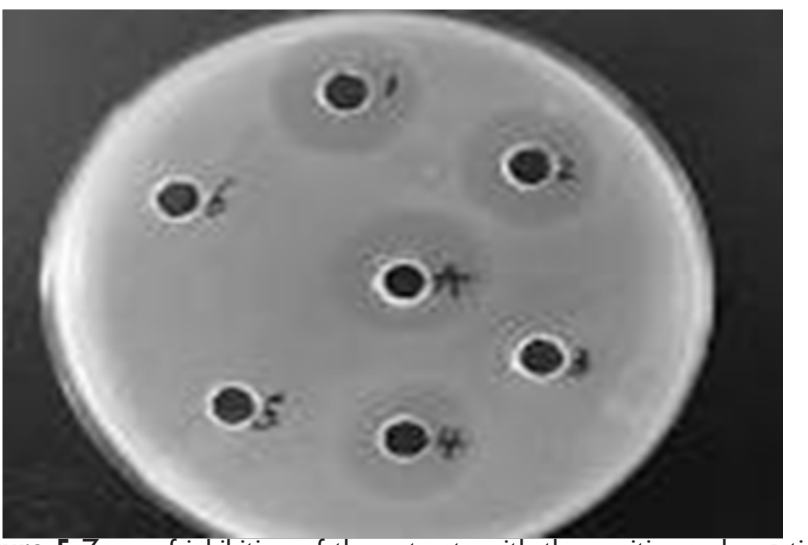

Figure 5 Zone of inhibition of the extracts with the positive and negative control. I=chloroform extract, 2=methanolic extract, $3=$ =xtract free chloroform, 4=acetone extract, $5=$ extract free methanol, $6=$ extract free acetone and $7=$ positive control.

Table 3 Preliminary screening of antimicrobial activity of methanol, acetone and chloroform extracts of andrographis paniculata leaf

\begin{tabular}{lllll}
\hline $\begin{array}{l}\text { Test } \\
\text { organisms }\end{array}$ & $\begin{array}{l}\text { Concen- } \\
\text { tration } \\
(\mathbf{m g} / \mathbf{m l})\end{array}$ & Inhibition zone diameter & (mm) \\
\hline & & Chloroform & Methanol & Acetone \\
\hline Escherichia coli & 400 & 25.4 & 24.6 & 24.3 \\
& $25\left(\mathrm{RSD}^{*}\right)$ & 25.3 & 25.3 & 25.3 \\
$\begin{array}{l}\text { Staphylococcus } \\
\text { aureus }\end{array}$ & 400 & 30 & 26.5 & 25.8 \\
& $25\left(\mathrm{RSD}^{*}\right)$ & 31.1 & 31.1 & 31.1 \\
Aspergillus niger & 400 & 22.5 & 20.3 & 17.2 \\
& $25\left(\mathrm{RSD}_{2}\right)$ & 23.4 & 23.4 & 23.4 \\
Candida & 400 & 20.3 & 15.4 & 16.2 \\
albicans & $25\left(\mathrm{RSD}_{2}\right)$ & 23.5 & 23.5 & 23.5 \\
\hline
\end{tabular}

RSD*, Reference standard drug $25 \mathrm{mg} / \mathrm{ml}$ (Azithromycin), RSD*, reference standard drug $25 \mathrm{mg} / \mathrm{ml}$ (Fluconazole).

Table 4 Minimum inhibitory concentration (MIC) based on microbial turbidity

\begin{tabular}{|c|c|c|c|c|c|c|}
\hline \multirow{2}{*}{$\begin{array}{l}\text { Test } \\
\text { organisms }\end{array}$} & \multirow[t]{2}{*}{ Extract } & \multicolumn{4}{|c|}{ Concentration (mg/ml) } & \multirow[t]{2}{*}{ MIC } \\
\hline & & 200 & 100 & 50 & 25 & \\
\hline \multirow[t]{3}{*}{ Escherichia coli } & Chloroform & - & - & - & + & 50 \\
\hline & Methanol & - & - & + & + & 100 \\
\hline & Acetone & - & - & ++ & ++ & 100 \\
\hline \multirow[t]{3}{*}{$\begin{array}{l}\text { Staphylococcus } \\
\text { aureus }\end{array}$} & Chloroform & - & - & - & + & 50 \\
\hline & Methanol & - & - & + & ++ & 100 \\
\hline & Acetone & - & - & + & ++ & 100 \\
\hline \multirow[t]{3}{*}{$\begin{array}{l}\text { Aspergillus } \\
\text { niger }\end{array}$} & Chloroform & - & - & + & + & 100 \\
\hline & Methanol & - & + & ++ & ++ & 200 \\
\hline & Acetone & + & + & ++ & ++ & - \\
\hline \multirow[t]{3}{*}{$\begin{array}{l}\text { Candida } \\
\text { albicans }\end{array}$} & Chloroform & - & - & + & + & 100 \\
\hline & Methanol & - & + & ++ & ++ & 200 \\
\hline & Acetone & + & ++ & ++ & ++ & - \\
\hline
\end{tabular}

+ , Microbial growth, ++, Profuse microbial growth, -, No microbial growth

Citation: Bassey EE, Ifeayinwa O, Onuorah C, et al. Photochemical screening and in vitro antimicrobial analysis of chloroform, methanol and acetone extracts of leaves of Andrographis paniculata. Int J Mol Biol Open Access. 2019;4(2):38-44. DOI: I0.I 5406/ijmboa.2019.04.00096 
Table 5 Minimum lethal concentration (MLC) based on microbial growth

\begin{tabular}{|c|c|c|c|c|c|c|}
\hline \multirow[t]{2}{*}{ Test Organisms } & \multirow[t]{2}{*}{ Extract } & \multicolumn{4}{|c|}{ Concentration (mg/ml) } & \multirow[t]{2}{*}{ MLC } \\
\hline & & 200 & 100 & 50 & 25 & \\
\hline \multirow[t]{3}{*}{ Escherichia coli } & Chloroform & - & + & + & ++ & 200 \\
\hline & Methanol & - & + & ++ & ++ & 200 \\
\hline & Acetone & ++ & + & ++ & ++ & - \\
\hline \multirow[t]{3}{*}{ Staphylococcus aureus } & Chloroform & - & - & + & ++ & 100 \\
\hline & Methanol & - & + & + & ++ & 200 \\
\hline & Acetone & - & + & ++ & ++ & 200 \\
\hline \multirow[t]{3}{*}{ Aspergillus niger } & Chloroform & - & + & ++ & ++ & 200 \\
\hline & Methanol & + & ++ & ++ & ++ & 200 \\
\hline & Acetone & + & ++ & ++ & ++ & - \\
\hline \multirow[t]{3}{*}{ Candida albicans } & Chloroform & - & + & ++ & ++ & 200 \\
\hline & Methanol & - & + & ++ & ++ & 200 \\
\hline & Acetone & + & + & ++ & ++ & - \\
\hline
\end{tabular}

+ Microbial growth, ++ Profuse microbial growth, - No microbial growth

\section{Conclusion}

According to the results obtained in this study, one is poised to arrive at the conclusion that Andrographis paniculata is a strong natural antimicrobial plant, with broad spectrum potential for treatment of both bacterial and fungal infections and other disease conditions. Thus, they can be used in the treatment of infectious diseases caused by resistant microbes. Plant tissues contain secondary metabolites with antibacterial and antifungal activities and thus are sources of natural bioactive molecules to control pathogens that cause disease in humans.

In addition, this research provided more scientific supporting gravels in favor of the users of this plant, both for food preparation and therapeutic purpose to explore more of its potential qualities. There is no doubt that plants have continued to offer a large range of natural compounds, belonging to different molecular families, which have various properties to humans. Obviously, traditional medicinal plants are cheaper than the orthodox medicines which are not only expensive but also not readily available to the rural dwellers. This calls for more research in the use of traditional (natural) medicinal plants and the validation of the use of herbs in various African localities and across the World in order to integrate them into health care system. This also borrow further credence from the present agitation on the use of natural products (such as green vegetables and fruits) over synthetic products (drugs) as tools for improving body immunity and good health. The test organisms were more sensitive to the chloroform extracts than the methanol and acetone, showing that the potential of plant extract is in part dependent on the solvent used.

\section{Acknowledgments}

None.

\section{Conflicts of interest}

The author declares there is no conflicts of interest.

\section{References}

1. Bewaji CO, Olorunsogo OO, Bababunii EA. Sickle cell membranebound(Ca2+ and $\mathrm{Mg} 2+)$ - ATPase: Activation by 3, 4,-dihydro-2, 2-dimethyl-2H-1-1-benzopyran-6-butyric acid. A novel anti-sickling agent. Cell Calcium. 1985;6(3):237-244.

2. Perry LM. Medicinal plants of East Southeast Asia: Attributed Properties and Uses. Cambridge, 1980.

3. Levita J, Nawawi A, Mutalib A, et al. Andrographolide: A Review of its Anti-inflammatory Activity via Inhibition of NF-kappaB Activation from Computational Chemistry Aspects. International Journal of Pharmacology. 2010;6(5):569-576.

4. Akowuah GA, Zhari I, Norhayati I, et al. HPLC and HPTLC densitometric determination of andrographolides and antioxidant potential of Andrographis paniculata. Journal of Food Composition Analysis. 2006;19(2-3):118-126.

5. Bajpai VK, Rahman A, Kang SC. Chemical composition and antifungal properties of the essential oil and crude extracts of Metasequoia glyptostroboides Miki ex Hu. Industrial Crop Production. 2007;26:2835 .

6. Acda MN. Toxicity, tunneling and feeding behavior of the termite, Coptotermes vastator, in sand treated with oil of physic nut, Jatropha curcas. J Insect Sci. 2009;9:1-7.

7. Anjana S, Rani V, Padmini R. Antibacterial Activity of Some Medicinal Plants used by Tribals against UTI Causing Pathogens. World Applied Science Journal; 2009;7(3):332-339.

8. Bera D, Lahiri D, Nag A. Studies on natural antioxidant for stabilization of edible oil and comparison with synthetic antioxidants. Journal of Food Engineering. 2006;74:542-545.

9. Bohm BA, Kocipai Abyazan R. Flavonoids and condensed Tannins from leaves of Hawaiian Vaccinium vaticulatum and V. Calycinium. Pac Sci. 1994;48(4):458-463.

10. Oomah DB. Isolation, characterization and assessment of secondary metabolites from plants for use in human health. PBI Bull. 2003;13-20.

11. Harborne JB. Phytochemical Methods: A Guide to Modern Technique of plant Analysis. 1973. 
12. Harborne JB. Phytochemical Methods A guide to modern techniques of plant analysis. $3^{\text {rd }}$ Ed. New York. 1998.

13. Sofowora A. Medicinal plants and Traditional Medicine in Africa. Journal of Pharmaceutical Sciences. 1985;74(3):364.

14. Senthilkumar PK, Reetha D. Screening of anti-microbial properties of certainIndian medicinal plants. J Phytol. 2009;1(3):193-198.

15. Garba I, Umar AL, Abdulrahman AB, et al. Phytochemical and Antibacteria Properties of Garlic Extracts. Bayero Journal of Pure and Applied Sciences. 2013;6(2):45-48.

16. Obdoni BO, Ochuko PO. Phytochemical Studies and Comparative efficacy of the Crude Extracts of some Homostatic Plants in Edo and Delta State of Nigeria. Glob J Pure Appl Sci. 2001;8b:203-208.

17. Edeogal HO, Okwu DE, Mbaebie BO. Phytochemical constituents of some Nigerian Medicinal plants. African journal of Biotechnology. 2005;4(7):685-688.

18. Moazzem SM, Shakhawat MD, Jahidul M, et al. Comparative Preliminary Phytochemical and Biological Investigations on Andrographis paniculata (Nees) and Aristolochia indica (Linn). Der Pharma Chemica. 2014;6(3):332-338.

19. Guillen MD, Manzanos MJ. Composition of the extract in dichloromethane of the aerial parts of a Spanish wild growing plant Thymus vulgaris L. Flavour \& Fragrance Journal. 1998;13:259-262.

20. Sokmen A, Jones BM, Erturk M. The in vitro antibacterial activity of Turkish plants. J Ethnopharmacol. 1999;67(1):79-86.

21. Akindele AJ, Adeyemi OO. Anti inflammatory activity of the aqueous leaf extracts of Byrsocarpus coccineus. Fitoterapia. 2007; 78:25-28.

22. Aiyelaagbe OO, Osamudiamen PM. Phytochemical screening for active compounds in Mangifera indica. Plant Sci Res. 2009;2(1):11-13.

23. Adelheid Brantner, Edith Grein. Antibacterial activity of some plan extracts used externally in traditional medicine. J Ethnopharmacol. 1994;44(1):35-40.
24. Lalitha TP, Jayanthi P. Preliminary studies on phytochemicals and antimicrobial activity of solvent extracts of Eichhornia crassipes (Mart.)Solms. Asian J Plant Sci Res. 2012;2(2):115-122.

25. Meenu Sharma, RG Sharma, RD Rawat, et al. Evaluation of Phytochemical and antibacterial activity of hot and cold methanolic extract of leaves and whole plant of andrographis paniculata. Int J Chem Sci. 2011;9(3):960-968

26. De M, Krishna De A, Banerjee AB. Antimicrobial screening of some Indian spices. Phytother Res. 1999;13(7):616-618.

27. Okwu DE. Evaluation of the Chemical Composition of indigenous spices and Flavouring Agent. Global J Pure and Applied Sci. 2001;7(3):455459.

28. Adekunle AA, Ikumapayi AM. Antifungal Property and Phytochemical Screening of the Crude Extracts of Funtumia elastica and Mallotus oppositifolius. West Indian Med J. 2006;55(6):219-223.

29. De Lucca A, Clevaland T, Rajasekara K, et al. Fungal properties of CAY1, a plant saponin, for emerging fungal pathogens. 45th Interscience Conference in Antimicrobial agents and Chemotherapy. 2005.

30. Coon JT, Ernst ET. Andrographis paniculatain the Treatment of Upper Respiratory Tract Infections: Assystemic review of safety and efficacy. Planta Med. 2004;70(4):293-298.

31. Adegboyega AM, Oyewole BM. Phyto chemical Screening and Antimicrobial Activities of Leaf Extracts of Andrographis paniculata. International Journal of Science and Research. 2013;4(6):2319-7064.

32. Baerceloux DG, Bond GR, Krenzelok EP, et al. American Academy of Clinical Toxicology on the treatment Guidelines for Methanol Poisoning. J Toxicol Clin Toxicol. 2002;40(4):415-446.

33. Aliyu AB, Musa AM, Sallau MS, et al. Proximate composition, mineral elements and anti-nutritional factors of Anisopus mannii N.E. Br. (Asclepiadaceae). Trends Appl Sci Res. 2009;4(1):68-72.

34. Aiyer KN, Kolammal M. Pharmacognosy of Ayurvedic Drugs, 1962. 